\title{
sciendo
}

\section{Father Professor BORIS BOBRINSKOY (1925-2020): A Theologian of the Spiritual Experience}

\author{
SERAFIM JOANTĂ
}

My words on Father Boris does not raise the claim of an academic speech; it is the mere testimony of a spiritual son who had him as a mentor for elaborating a paper with the title "The Tradition of Monastic Ascetism in the Romanian Lands," and as a father confessor until he passed to the Lord on August 7th, 2020. When, in the autumn of 1982, I arrived at the "St. Serge" Institute with a scholarship offered by the Catholic Church, Father Boris told me that he was interested in Romanian monastic ascetism and in Abbot Paisie Velicicovski (1722-1794), the initiator of the renaissance of the monastic ascetism on Mount Athos, by turning to account the old writings referring to the "Jesus Prayer." The monastic ascetic spirit, rekindled by Abbot Paisie, would be spread throughout the Greek world by St. Nicodemus of the Holy Mountain (1749-1807) by publishing the Philokalia (1782), and into the Slavic and Romanian language Orthodoxy by Saint Paisie himself and by his disciples, after his return from the Holy Mountain back to Moldova (1763).

Not long before, Father Boris, as leader of an initiative group, had decided to translate the Philokalia of St. Nicodemus into French; a work which he would supervise until its publishing. This famous "collection from the writings of the Holy Fathers, which shows how a man can cleanse, enlighten and accomplish himself" (as it is stated on the title page) has had and still has great influence on the spiritual life in the Orthodox world. It had been a "vademecum" in Father Boris' life ever since the time when he was a university student.

\section{Biographical data, education, and academic titles}

Born in Paris in 1925, into an aristocratic family of Russian immigrants, Boris Bobrinskoy completed his formal education at the Jesuit Colleges in Namur and Paris, then at the "St. Serge" Institute, from where he would graduate in 1949 with the graduation paper: "Mystère du carême chez les Pères orientaux du 4eme siècle." Between 1949-1951, he continued his aca-

\footnotetext{
* Serafim Joantă, Romanian Orthodox Metropolitan of Germany, Central and Northern Europe, Fürtherstrasse, 166, 90429 Nürnberg, Deutschland, serafim@mitropolia-ro.de. Translated by Mirela Kulin.
} 


\section{In Memoriam /}

demic education at the Theology Faculty in Athens, then, on Mount Athos, he participated in editing the works of St. Gregory Palamas and became interested in the thinking of St. Nicholas Cabasila, authors who would inspire him throughout his entire life. Between 1965-1967, he studied at the Protestant Theology Faculty in Neuchâtel (Switzerland), and in 1987 he obtained a PhD in theology with the thesis paper: "Le repos de l'Esprit dans le Christ." He was awarded honoris causa PhD of the Theology Faculties in Fribourg (2000), Alba Iulia (2001), Cluj-Napoca (2002), and St. Vladimir (New York, 2003).

\section{Professional activity}

In 1954, Father Boris Bobrinskoy was named Professor of Dogmatic Theology at the "St. Serge" Institute, where he would teach until 2006. Between 1993-2010 he was Dean of the Institute.

After having married Elena Disterlo, with whom he had three children, he was tonsured as a priest in 1959, and later he was assigned to the French-speaking "Holy Trinity" parish from the crypt of the Alexander Nevsky Cathedral in Paris. As a professor of theology and a priest, Father Boris committed himself, heart and soul to the intellectual and spiritual education of his students and parishioners, for whom he had a "compassionate heart", like a true parent. His lectures were followed not just by students, but also by "auditeurs libres," Parisian intellectuals interested in knowing about Orthodoxy or deepening their knowledge of it. They were published in Le Mystère de la Trinité (Cerf, 1996), and Le Mystère de l'Église (Cerf, 2003). Father Boris also was one of the main inspirers of the publication "Contacts" (established in 1949), an Orthodox magazine for spirituality and theology. He wrote hundreds of study papers, articles, comments, and spiritual meditations, a part of which are gathered in volumes such as: Communion $d u$ Saint-Esprit (Abbaye de Bellefontaine, 1992), La Compassion du Père (Cerf, 2000), La Vie liturgique (Cerf, 2000), Je suis venu jeter le Feu sur la terre (Éd. du Désert, 2003).

Some of them have been translated into several languages. In Romanian, the Biblical Institute and Orthodox Mission Publishing House (of the Patriarchy) has published: "Împărtăşirea Sfântului Duh" (Editura Institutului Biblic și de Misiune al BOR, 1999) and "Taina Preasfintei Treimi" (2005), and the Renassterea Publishing House (of the Cluj Metropolitan Office) has published "Compasiunea Tatălui" (2017).

A major concern of Father Boris was that of researching the Mystery of the Holy Spirit in the life of the Church. He did this from a pastoral perspective, and in a language inspired from the richness of the Church cult, 
with the awareness that "speaking of the Spirit means letting yourself be carried by It into a doxological impetus," as Olivier Clément remarked about it. That is why, in all the Father's writings, one can feel the inspiration and warmth of the Spirit, as well as the Spirit of the Holy Fathers, from whom he abundantly quotes. For him, the Church itself is a permanent epiclesis, a never-ending Pentecost, which tends to eschatological plenitude. His essays and books are read easily since they are written with the consciousness of the servant who is up to build the Church pleroma, and not just a segment of it. That is why his style is often spoken, simple and profound at the same time.

Here is just a sentence related to the rapport between tradition and freedom in the Church life, of high importance, and a permanently current topic:

In the Church there is a fundamental balance, yet not acquired once and for all, but which always needs renewal, between the principle of tradition, obedience, order, the sacramental, liturgic forms on one hand, and the principle of freedom, creation, one's own responsibility, the unreducible integrity of the human person, of the local community, of the godly grace, which internalises the forms, places, times, and which ensures a unique vertical relationship between the person and God, between the local Gathering and the Master of all, on the other hand. In this respect, the inspiration of the Spirit is always to be renewed, it is not coded, it is embodied; the Truth is always alive, never limited by dogmatic formulae and rules which express and delimit it (Împărtăşirea Sfântului Duh, 380-381).

\section{Pastoral minister}

Father Boris was outstanding as both a performer of the Divine Liturgy and a preacher. He was convinced that the Divine Liturgy must be celebrated such that it can be internalised by the believers. That is why he started the Divine Liturgy with the prayer: "O Heavenly King...," spoken by all believers, and he read the Liturgical Anaphora and Epiclesis out loud so that all people present be able to confirm the priest's prayer with their "Amen." He also insisted on forgotten liturgical gestures, like the kiss of peace, done not only by the priests in the altar but also by the believers by shaking hands. The believers witnessed his intense experience, sometimes up to tears, especially during the divine services within Great Lent or at Pentecost. As a preacher, he knew how to find simple and accessible words for everyone to discover the spiritual meaning of the pericopes from the Apostles and Gospel.

Father Boris was active not only in the parish assigned to him as a rector (parish priest), but also in the life of the Orthodoxy in Western Europe, 


\section{In Memoriam /}

being one of the founders of the "Orthodox Fraternity in Western Europe" (1971), and its leader until toward the end of his life. Designed as a tool for manifesting the unity and testimony of the Church in the world, the Fraternity offers a space for dialogue and friendship, where everyone can deepen one's faith and know oneself better, surpassing jurisdictional, ethnic, language or cultural barriers. Its triannual congresses are true events of Orthodoxy in Western Europe, with hundreds of participants, particularly young people, and with great influence on ecclesiastic life. Father Boris also contributed substantially to root Orthodoxy on French soil, promoting liturgical service in the local language, for which he took care that the divine services were translated into French.

For the persecuted Christians in Russia, he had been responsible for the radio broadcast "Voix de l'Ortodoxie" in Russian for decades and broadcasted sermons, catechesis, and information from the Christian world at regular time intervals.

\section{Ecumenical involvement}

Throughout his entire life, Father Boris was a maker of peace and unity. Since he had a compassionate heart, he suffered because of the discord among Christians and the conflicts within his own Church. He strived to live and promote not just an intellectual ecumenism, "bien-pensant", but particularly a spiritual ecumenism, inspired by prayer, being convinced that only prayer widens the heart so it can encompass all humans. In this sense, he was closely linked to the ecumenical community at Grandchamp in Switzerland. He was an Orthodox delegate in the commission "Faith and Constitution" of the World Council of Churches, and a member of the Mixed Committee for Catholic-Orthodox and Orthodox-Protestant Theological Dialogue in France for many years. Between 1992 and 2004 he was co-chairman of the "Ecumenical Society for Biblical Studies," which would publish a new ecumenical translation of the Bible in French. As a professor of dogmatics, he taught for many years, until his retirement, beside colleagues of other confessions, at the Institute for Ecumenical Studies in Paris. Devoid of any Orthodox triumphalism, Father Boris was aware of the historic deficiencies of all Christian traditions. As regards the Orthodox Church, he mourned the lack of conciliarity, particularly at the pan-Orthodox level.

Related to the divergence between East and West on the topic of "Filioque," Father Boris wondered how can it be that the Spirit of love and unity be an object of discord and separation between Christians, and he tried to transfer the issue from the juridical level, always reducing, onto the level of ecclesiastic experience. He wrote: 
We need to insist on the fundamental importance of the trinitary experience at the level of the Church life, a place of revelation and communion with the divine Trinity. Any new life experience - as a life in the Spirit, as a birth through the Spirit and in the Spirit... shall lead to a theological vision of the full reciprocal communion of the Son and the Spirit, as a Spirit Who rests over the Son in plenitude, and Who is the Spirit of the Son. Any spiritual experience that will tend to minimise the role of the Holy Spirit, reducing It to a simple function of Christ's presence, will lead to a unilateral conception on the Spirit as coming from the Son, and being subordinated to Him from a causal viewpoint (Taina Preasfintei Treimi, 345).

About the need of joint prayer for Christian unity, Father Boris wrote memorable pages. He was convinced that unity manifests itself especially "deep within the eucharistic chalice":

Unity is experienced and announced deep within the eucharistic chalice; around the altar or the table of the Holy Supper is where this unity manifests itself the fullest. And also, the drama of the separation of Christians is felt with the highest intensity in the impossibility of intercommunion. This is why the Eucharist is a challenge to the current situation of the Church, of its installation into separation. It is a challenge to the separation among Christians, as Christ cannot be divided, because His Body, the Church, is One by its nature, by its promise, by its calling. Thus, separation is an absurdity and a scandal, and its acceptance as a rule contradicts and betrays the will of the Lord. We thus need to pray more ardently so that the madness of disunion be overcome at its root and origin... (Taina Preasfintei Treimi, 458-459).

\section{The "St. Serge" Institute or a different way of doing theology}

Father Boris identified himself with the school which educated and trained him, and which he devoutly served all his life. He was aware, like all the professors of the Institute, that, by being the first Orthodox theology school in Western Europe, it had the vocation to not only educate and train priests for the Orthodox diaspora in the Western world but to also be a meeting place between the Western and Eastern Christian tradition. Here, in Paris, the Orthodox realised the "Babylonian captivity" (Georges Florovsky) of their theology, tributary to the Western scholastics, and try to liberate themselves from it by returning to the Spirit of the Holy Fathers. Inspired by the spirit at "St. Serge," great French theologians, like Henri de Lubac and Jean Daniélou, also feel the need to renew Catholic theology and take the initiative to translate into French the works of the Holy Fathers and the church writers from 


\section{In Memoriam /}

the first Christian centuries. Thus, has appeared, since 1943, the collection "Sources chrétiennes," which counts more than 600 volumes today.

For their ecumenical openness, professors Nicolas Afanassieff and Paul Evdokimov from "St. Serge" were invited as observers to the works of the Second Vatican Council. In the decree on the Church, the Fathers of the Council were inspired from the eucharistic ecclesiology of Father Afanassieff, who saw, in the Eucharist presided by the bishop, the concretisation of the universal Church, thus turning to account the importance of the local Church and the conciliarity.

Special ecumenical events in the Institute's life are also "Les Semaines liturgiques de St. Serge," organised at the end of each academic year, starting with 1953, where Orthodox, Catholic, and Protestant specialists participate, as well as a varied audience willing to deepen its own liturgical tradition and to know the similarities between the various traditions.

On the liturgical line, we need to also mention his titles of $\mathrm{PhD}$ in Theology, awarded in co-patronage by the "St. Serge" Institute and the Catholic Institute in Paris.

What I gladly noticed since the moment I arrived at "St. Serge" was the vivid connection between its liturgical life and academic studies. The ancient principle: "lex orandi, lex credenda" ("the law of prayer is also the law of faith") or the interdependence between prayer and faith, in its theological expression, characterised the inner life of the Institute. From the first days, I heard that Father Serge Bulgakov (†1944) was not holding his dogmatics lecture unless he served the Divine Liturgy together with his students before that, because, as he said, "in our lecture we try to express the mystical experience lived in the church; if we do not pray, we do not have what to express, since theology is the expression of prayer." Without prayer, there is no theology! Certainly, Father Serge was inspired here from the teaching of Evagrius Ponticus, who said: "a theologian is he who truly prays, and he who truly prays is a theologian."

The professors at "St. Serge" were aware that theology can only be done in an ecclesial, liturgical context, by always letting itself be inspired by the Church's prayer and askesis. That is why the liturgical life at the Institute was very intense, with daily services, in the mornings, and evenings. I am touched when remembering the services during Lent, especially in the first week, when no lectures were held, and the professors were participating together with the students at the divine service, which lasted for more than four hours, and all were making genuflections, with the knees and forehead to the ground, following the traditional norms.

As a function of the Church, the theology serves for its edification, for the salvation of God's people. There is an accomplished unity between the 
Holy Mass, Spirituality, Theology, and Deaconry. Theology can be regarded as the backbone of the Church. She protects the Church from falling into the extremes of sentimentalism or fundamentalism. In this regard, Olivier Clement, a professor at the Institute, was telling about a dialogue with Vladimir Lossky, who said that we need a theological system to convey faith, but, since God is above any system and any word, after we use the system, we need to "mine it," so that we do not turn into slaves of the system. Saint Gregory of Nyssa also said that dogmas can become idols if they are emptied of love if we use them as weapons against those who believe otherwise. "The letter kills, and the Spirit makes alive" (2 Cor. 3:6).

About Father Boris, his successor at the lecture chair, Professor Michel Stavrou, says:

Nourished from the writings of the authors in the great times of the Institute (Serge Bulgakov, Cyprien Kern, Georges Florovsky, Nicolas Afanassieff, Paul Evdokimov) and by Vladimir Lossky, he shared a lot not only with his colleagues from the new generation of the Institute, like Alexandre Schmemann, Jean Meyendorff and Olivier Clement, but also with many other theologians, be they Orthodox, like Dumitru Stăniloae and Jean Zizioulas, or of other Christian traditions, like Yves Congar and Henri de Lubac, or like Oscar Cullman and Jean-Jacques Alleman. In fact, Father Boris was sharing his own research with everyone, which, as any true theology, had a directly existential significance.

As a confessor, Father Boris insisted on both confession and communion with the Lord's Body and Blood, with the required preparation, at each Divine Liturgy. At confession, he used to ask me every time if I came to have in my heart, ceaselessly, "Jesus Prayer." I answered him that I was far from that state. That is why he prompted me to keep praying, as the heart widens and encompasses all humans only if it prays a lot. He also said to me that all issues and problems in life are solved through prayer.

I close this word by quoting Michel Stavrou again:

By taking on his duty as a pastor with infinite seriousness, without taking himself too seriously, Father Boris knew how to keep his candid and good-humoured character, his carefree way and his humour, which came from his trust in God, and which were amazingly allied with a rare vigour, enhanced by his tall stature and by his bright face, until the end.

I am convinced that Father Boris has been welcomed into the host of the Saints and that, like them, he mediates for those who call upon him for help. That is why I say daily: "Father Boris, pray for me, the sinner"! 